Pehlivanlı, Esra ve Gözde İkizer (2020). "Kırsal ya da Kentsel Bölgelerde Evlilik:

Evlilik Doyumu ve Erken Dönem Uyum Bozucu Şemalar Üzerine Bir İnceleme”. Uludağ Üniversitesi Fen-Edebiyat Fakültesi Sosyal Bilimler Dergisi, C. 21, S. 38, s. 361-395.

DOI: 10.21550/sosbilder.593401 Araştırma Makalesi

\title{
KIRSAL YA DA KENTSEL BÖLGELERDE EVLİLIK: EVLİLİK DOYUMU VE ERKEN DÖNEM UYUM BOZUCU ŞEMALAR ÜZERİNE BİR İNCELEME*
}

\author{
Esra PEHLIVANLI** \\ Gözde İKİZER***
}

Gönderim Tarihi: Temmuz 2019

Kabul Tarihi: Aralık 2019

\section{ÖZET}

Bu çalışmanın amacı yaşanılan yerin ve erken dönem uyum bozucu şemaların evli bireylerin evlilik doyumu üzerindeki etkisini incelemektir. Çallşmanın örneklemi, 120 'si kursal ve 168 'si kentsel bölgelerde yaşayan 268 evli bireyden (134 kadin ve 134 erkekten) oluşmuştur. Katılımcılara, sırasılyla Young Şema Ölçeği-Kısa Form 3, Çift Uyum Ölçeği ve demografik bilgi formu uygulanmıştır. Bulgular, kırdaki evli bireylerin evlilik doyumu düzeyinin kentte yaşayanlara kıyasla daha yüksek olduğunu göstermiştir. Bazı şema boyutlarında kırdaki katılımcıların puanlarının daha yüksek olduğu bulunmuştur. Ayrlca, kırda ve kentte yaşayanlarda evlilik doyumunu farklı erken dönem uyum bozucu şemaların yordadığı görülmüştür. Evli bireyler ve / veya çiftler ile çalışan ruh sağllğ uzmanlarının, bu bireylerin evlilik doyumunun kırsal ya da kentsel bölgelerde farkll değişkenlerden etkilenebileceğini göz önünde bulundurmaları önemli görünmektedir.

${ }^{*}$ Bu çalışmanın bulguları, 5 Temmuz 2019 tarihinde 23. Ulusal Psikoloji Öğrencileri Kongresi'nde sözlü bildiri olarak sunulmuştur.

** (D) Psikolog, TOBB Ekonomi ve Teknoloji Üniversitesi Fen-Edebiyat Fakültesi Psikoloji Bölümü, epehlivanli@etu.edu.tr

*** (D) Dr. Öğr. Üyesi, TOBB Ekonomi ve Teknoloji Üniversitesi Fen-Edebiyat Fakültesi Psikoloji Bölümü, gikizer@etu.edu.tr

Uludağ Üniversitesi Fen-Edebiyat Fakültesi Sosyal Bilimler Dergisi Uludağ University Faculty of Arts and Sciences Journal of Social Sciences

Cilt: 21 Sayl: 38 / Volume: 21 Issue: 38 
Anahtar Kelimeler: evlilik doyumu, erken dönem uyum bozucu şemalar, yaşam yeri, kırsal, kentsel

\title{
Marriage in Rural or Urban Areas: An Exploration of Marital Satisfaction and Early Maladaptive Schemas
}

\begin{abstract}
The aim of the current study was to investigate the impact of place of residence on marital satisfaction and early maladaptive schemas of married individuals. The sample consisted of 268 married individuals (134 females and 134 males) including 120 participants from rural and 168 from urban areas. The participants were given the Young Schema Questionnaire-Short Form 3, the Dyadic Adjustment Scale, and a demographic information form. Findings showed that the level of marital satisfaction was higher in individuals living in rural areas compared to individuals in urban areas. Furthermore, it was found that participants from rural areas had higher scores at some of the schemas. In addition, different early maladaptive schemas predicted marital satisfaction for individuals in rural or urban areas. It seems important for mental health professionals working with married individuals and / or couples to take into consideration that marital satisfaction might be affected by distinct factors in rural and urban areas.
\end{abstract}

Key words: marital satisfaction, early maladaptive schemas, place of residence, rural, urban

\section{Giriş}

Evlilik, toplumdaki birçok birey için oldukça yakın birlikteliği içeren bir ilişki türüdür. Bireyler evlilik ilişkilerinden doyum aldıklarında, bu bireylerin yaşamlarına anlamlı bir katkı sunmaktadır. Evlilik doyumu, kişinin kendi evliliğine karşı olumlu tutuma sahip olmas1 olarak tanımlanmaktadır (Roach vd. 1981). Roach ve meslektaşları (1981) doyumun, sabit bir özellikten ziyade, zaman içinde değişime açı bir tutum olduğunu ve kişinin önemli yaşam deneyimlerinden etkileneceğini belirtmiş̧lerdir. Alan yazında, evlilik 
doyumu ile birlikte evlilik uyumu, niteliği, mutluluğu gibi terimler de benzer kavramı ifade etmek için kullanılmaktadır (Bird vd. 1994).

Evlilik doyumunu açıklayan etkenlerin çoklu olduğu düşünülmektedir. $\mathrm{Bu}$ alandaki ilk kavramsallaştırmaları yapan araştırmacılardan olan Snyder (1979), evlilik doyumunun; geleneksellik, evlilikle ilgili genel sıkıntılar, duygusal iletişim, sorun çözmeye yönelik iletişim, birlikte geçirilen zaman, maddi konular hakkındaki anlaşmazlıklar, cinsel hoşnutsuzluk, rol yönelimi, ailesel sıkıntı öyküsü, çocuklarla ilgili hoşnutsuzluk ve çocuk bakımı ile ilgili çatışmaları içeren birçok faktör ile açıklanabilecek bir kavram olduğunu belirtmektedir. Halford ve meslektaşlarına (1997) göre, evlilik doyumunu artıran dört temel özellik bulunmaktadır. Bunlar, (1) evlilikte olumlu etkileşim (ör. birlikte zaman geçirme, ortak etkinliklerde bulunma), (2) etkili iletişim ve çatışmaların başarılı yönetimi, (3) eşe yönelik olumlu ilgi ve (4) olumlu ilişki şemasıdır (ör. ilişki ve tarihçesi hakkında ortak, olumlu algılar). Bradbury ve meslektaşları (2000), 1990'larda evlilik doyumu hakkında yapılan çalışmaları incelediklerinde, duygulanım, fizyoloji, örüntüler, bilişler, şiddet ve sosyal destek gibi değişkenleri içeren kişilerarası süreçlere yönelik birçok çalışma olduğunu rapor etmişlerdir. $\mathrm{Bu}$ açıdan, evlilik doyumunun çoklu değişkenlerden etkilendiği görülmektedir. Ülkemizde evlilik doyumu ile ilgili olarak yapılan kapsamlı bir çalışmada, Çağ vd. (2013) eş desteği, cinsel yaşam memnuniyeti ve eğitim düzeyinin evlilik doyumunu anlamlı olarak yordadığını göstermişlerdir.

Evlilik doyumu ile ilişkili olan bireysel etkenlerin arasında çeşitli bilişsel etkenler bulunmaktadır. Alan yazında, bilişsel etkenlerin evlilikte eşlerin ilişki doyumunu etkilediğine yönelik birçok kavramsallaştırma olduğu görülmektedir. Hatta birçok evlilik terapisi kuramı henüz oluşmamışken dahi, evlilik sorunlarını ele alırken bilişsel etkenlere odaklanmanın önemli olduğu görüşü evlilik ve çift terapistleri 
arasında yaygın olduğu belirtilmektedir (Tilden vd. 2005). Örneğin, Ellis (1986) evlilik ilişkilerinde sorunların, eşlerden biri ya da her ikisinin de diğer eşin davranışının ne olması gerektiği hakkında gerçekçi olmayan beklentilere ve inançlara sahip olmalarından kaynakladığını belirtmektedir. Baucom vd. (1989) ise ilişki sorunları ile ilgili bilişlere yönelik sundukları kapsamlı tipolojide; (a) seçici dikkat (ilişkide yaşanan olaylara belli bir açıdan bakma eğilimi); (b) atıflar (evlilik hayatıyla ilişkili eylemleri etkileyen faktörler hakkındaki çıkarımlar); (c) beklentiler (ilişkide belirli olayların oluşma olasılığına dair tahminler); (d) varsayımlar (insanlar ve ilişkilerin karakterleri hakkındaki inanışlar); ve (e) standartlara (insanlar ve ilişkilerin karakterlerinin nasıl olması gerektiğine dair inanışlar) odaklanmaktadırlar. Bilişlerin bu beş türü, Beck ve arkadaşlarının (1979) otomatik düşünce, şema, bilişsel hatalar gibi kavramlarında da yansitılmaktadir.

Kuramcıların evlilik doyumu ile bilişsel değişkenlerin ilişkisine yönelik yaptıkları vurgudan hareketle, mevcut çalışma erken dönem uyum bozucu şemalara odaklanmaktadır. Erken dönem uyum bozucu şemalar, genellikle çocukluk ve ergenlik dönemlerindeki deneyimlere bağlı olarak geliştiği düşünülen; anılardan, duygulardan, bilişlerden ve bedensel duyulardan oluşan, önemli bir dereceye kadar işlevsel olmayan, benlik algısını ve kişilerarası ilişkileri etkileyen ve yaşam boyunca sürekli tekrar eden kalıp ya da örüntüler olarak tanımlanmaktadır (Young 1999; Young vd. 1994; Young vd. 2003). Doğuştan mizaç yoluyla ya da çevrenin etkisiyle şekillenerek bireyleri etkileyen şemalar, bireylerin inanış kalıplarını oluşturmaktadır (Behary vd. 2016). Erken dönem uyum bozucu şemaların; kopukluk ve reddedilmişlik, zedelenmiş özerklik ve kendini ortaya koyma, zedelenmiş sınırlar, diğerleri yönelimlilik, aşırı tetikte olma ve bastırılmışlık şema alanlarını kapsayan 18 boyutu içerdiği düşünülmektedir (Young vd. 2003). 
Şema kuramına göre, çocukluk döneminde karşılanmayan temel ihtiyaçların giderilmesine yönelik baş etme yöntemleri yetişkinlikte de sıklıkla kullanılmaya devam edilmektedir. Böylece erken çocukluk döneminde ilişkilerde yaşanan sorunlar sonucunda oluşan bilişsel şemaların, yetişkinlik döneminde ilişkilerde sorunlara ve böylece, evlilik ilişkisinde doyumun azalmasına neden olabileceği ileri sürülmektedir (Rafaeli vd. 2013). Erken dönem uyum bozucu şemaların evlilik ilişkisinde boşanma gibi olumsuz sonuçlarla olan ilişkisi ele alındığında, şemaların evlilikte çatışma ve yakınlığın azalmasına neden olabileceği görülmektedir (Hatamii vd. 2015). Dumitrescu ve Rusu'ya (2012) göre erken uyum bozucu şemaların sayıca fazla olması, çiftlerde doyum düzeyinin düşük olmasına neden olmaktadır. Öyle ki, erken dönem uyum bozucu şemalardaki her 1-birimlik artış, ilişki doyumunda 3.8-birimlik düşüşe karşılık gelmektedir. Özellikle, duyguları bastırma, güvensizlik ve yüksek standartlar şemalarının evliliğin sonlanması ile ilişkili olabileceği gösterilmiştir (Yousefi vd. 2010). Ülkemizde evlilik doyumu ve erken dönem uyumsuz şemalar üzerine yapılan çalışmalarda (ör. Altun 2015; Kargın Güner 2014; Soysal 2017; Yıldız 2018), evlilik doyumunun genel olarak erken dönem uyumsuz şemalarına varlığı ile negatif ilişkili olduğu görülmüştür. Bununla birlikte, bu çalışmalarda bazı şema alanlarının doyum ile pozitif ilişki olduğuna ya da şemaların evlilik doyumunun yalnızca belli boyutlarıyla ilişkili olduğu bulguları temelinde evlilik doyumu ve erken dönem uyum bozucu şemalar hakkında özellikle ülkemizde yapılacak çalışmalara ihtiyaç olduğu görülmektedir.

Hem birey hem de toplum için aile önemli bir yere sahiptir. İnanış ve gelenekler, toplumsal değişim süreçleri, azınlık statüsü gibi etkenlerin yanı sıra, kır ve kent yerleşim yapıları da aileyi etkilemektedir (Giele 2013; Yıldırım 2011). Kırdaki yaşam daha ziyade aristokratik bir varoluşu desteklerken ve 'aile ilişkileri etrafinda' düzenlenirken; kentte daha 'akılcı ve mekanik' bir yaşam biçimi 
gözlenmektedir (Simmel 2009). Toplumu ihtiyaçlar ve işlevlere göre tanımlanmış bir sosyal sistem olarak gören Parsons'a (1956, Chambers 2012 'den) göre ise kır toplumunda aile geniş, ekonomik üretim birimi iken kent toplumunda ise küçük, hareketli tüketim birimidir. Kağıtçıbaş1 (2013) da Aile Değişim Kuramı'nda kentteki ve kırdaki ailelerinin farklı özellikleri olabileceğinden söz etmektedir. Kağıtçıbaşı'na (2013) göre bağımlı aile modeli kırsal bölgelerde daha yaygınken; bağımsız aile modeli orta sınıf kentsel bölgelerde ve duygusal bağlı aile modeli ise eğitimli ve kentli ailelerde daha yaygındır. Ayrıca ülkemiz genel olarak toplulukçu bir kültür olarak anılsa da eğitimli, genç ve kentte yaşayan kesimde bireyci özelliklerin yaygın olduğu bilinmektedir (Kağıtçıbaşı vd. 2014). Bu açıdan, ülkemizdeki kır ve kent alt gruplarının sosyokültürel özelliklerinin farklı olması beklenmektedir.

Evlilik eşler arasında kişisel bir bağlılık aracı olmakla birlikte, daha büyük toplumun sosyal ve yasal yaptırımlarına bir bağlılık da içermektedir (Bird vd. 1994). Bu nedenle, evlilik ilişkisi içinde bulunduğu sosyal yapıdan bağımsız düşünülemez. Yukarıda sözü edilen sosyokültürel farkların evlilik ilişkisine yansımaları olması mümkündür. Kırda ve kentte aile yaşamları ve ailenin kimlerle temas içinde olduğu konularında da farklar bulunmaktadır (Toth Jr vd. 2002). Buradan hareketle, evlilik doyumunu etkileyen ilişkisel ve bireysel değişkenlerin yanı sıra, aile yapısındaki olası değişimlere bağlı olarak çiftlerin beraber yaşadıkları yerin de evlilik doyumu üzerinde etkili olması olasıdır. Bununla birlikte evlilik doyumu bağlamındaki çalışmaların sıklıkla kent örneklemleri ile yapıldığı belirtilmiştir (Lamke 1989). Lamke'ye (1989) göre kırsalda yaşayan evlilerin daha fazla geleneksel cinsiyet rolüne sahip oldukları ve cinsiyet rollerinin evlilik doyumunu açıklamada önemli bir değişken olduğu düşünüldüğünde, kentlerde yaşayanlarda elde edilen bulguların kırsal örneklemlere genellenip genellemeyeceği açık değildir (Lamke 1989). Ülkemizde kırda ya da kentte yaşayan kadınların evlilik doyumu 
düzeylerinin incelendiğini bir tez çalışması (Kaya 2017) bulunmakla birlikte, bu çalışmada erkek katılımcıların yer almaması nedeniyle çalışma kısıtlı görünmektedir.

Evlilik ilişkisi içinde eşlerin doyumunun düşük olmasının evliliklerin boşanma ile sonuçlanmasına neden olması olasıdır. Boşanmanın genel olarak kentsel bölgelerde kırsal bölgelere kıyasla daha yüksek olduğu belirtilmektedir (McDaniel vd. 2019). İstatistikler temelinde ülkemizde de böyle bir eğilimin olabileceği izlenimi edinilmektedir. Örneğin Türkiye İstatistik Kurumu verilerine göre, ülkemizde 2018 yılında, boşanma oranının bir önceki yıla göre \%10,9 arttığı; kaba boşanma hızının binde 1.75 olduğu belirlenmiştir. Kaba boşanma hızının en yüksek olduğu iller sırasıyla İzmir, Muğla ve Antalya olurken; en düşük olduğu iller ise Hakkâri, Şırnak ve Siirt olmuştur. Güneydoğu bölgesinin tamamında ve Hakkâri ilinde kırsal nüfus 1980'den 2012 yılına dek sürekli olarak artış göstermiştir (Yılmaz 2015). Ayrıca, Türkiye İstatistik Kurumu'nun toplam nüfus ve Yılmaz'ın (2015) kırsal nüfus verisi temelinde bu illerdeki kırsal nüfusun toplam nüfusa oranı Türkiye ortalamasının üzerindedir. Yıldırım (2004) da T.C. Başbakanlık Devlet İstatistik Enstitüsü'nün 2000 yılındaki istatistikleri temelinde ülkemizde Batı bölgelerinde Doğu bölgelerine ve ekonominin geliştiği bölgelerde gelişmemiş bölgelere kıyasla boşanmanın daha sık olduğunu belirtmiştir. Genel olarak, eğitim düzeyi ve maddi durumun boşanmalarda belirleyici olduğu düşünülmektedir. Düşük eğitim düzeyinin, geleneksel cinsiyet rollerine sahip olmakla ilgili olabileceği belirtilmiştir (Arnett vd. 1987). Geleneksel cinsiyet rollerine sahip eşlerin olduğu evliliklerde, kadının kendini sınırlı ifade etmesi ya da sorunlara karşı boyun eğmesi eşlerdeki stresi ve psikolojik belirtilerin şiddetini artırabilmektedir (Yüksel vd. 2015). Eğitim düzeyine ek olarak, maddi sorunların eşlerde psikolojik stresi artırdığı ve bunun da, evlilik doyumunun azalmasına neden olabileceği gösterilmiştir (Kinnunen vd. 2004). Türkiye'de yüksek 
sosyoekonomik statüdeki ailelerde "aldatma, fikir ayrılığı, varlığın düzgün idare edilememesi” gibi nedenlerle boşanma daha yaygınken; düşük statüde "aile içi şiddet, erken evlilik, maddi sıkıntı" gibi konular daha öne çıkmaktadır (T.C. Aile ve Sosyal Politikalar Bakanlığı 2014: 176). Kent yaşamının getirdiği stres de kentteki boşanmalarda etkili olabilir (McDaniel vd. 2019). Bununla birlikte, McDaniel ve diğerlerine (2019) göre kırsal bölgelerde yaşayanların boşanma öncesi, sırası ya da sonrası kente taşınmaları ya da kırda yaşayan genç bireylerin eğitim ya da iş amacıyla kente göç etme ve orada evlenme eğilimleri nedeniyle de kentte boşanma hızının yüksek bulunuyor olması olasıdır.

Önceki çalışmalar temelinde, kentsel ve kırsal bölgelerde psikolojik sağlık göstergelerinin de farklılaşabileceği bilinmektedir. Örneğin, kentte ya da kırda yaşayan yoksul bireylerin iyilik hali kıyaslandığında, her ne kadar mutluluk ve depresyon puanları açısından gruplar arasında herhangi bir fark olmasa da, kentte yaşayanların sağlığını kırda yaşayanlara kıyasla daha iyi algılama eğiliminde olduğu görülmüştür (Amato vd. 1992). Buna karşın, herhangi bir psikolojik bozukluk görülme oranı ile duygudurum ve anksiyete bozukluklarının görülme oranının kentsel bölgelerde kırsal bölgelere kıyasla daha yüksek olduğu da gösterilmiştir (Peen vd. 2010). Bunun kültür ve sosyoekonomik farklılıkların yanı sıra, gen-çevre etkileşimi ile de açıklanabileceği belirtilmiştir. $\mathrm{Bu}$ açıdan, yaşanılan yerin, evlilik doyumu ya da erken dönem uyum bozucu şemalar ile yakından ilişkili olabileceği düşünülen psikolojik iyilik hali üzerindeki etkileri de henüz net olarak anlaşılamamıştır. $\mathrm{Bu}$ nedenle, yaşanılan yerin evlilikte bireysel ya da ilişkisel etkenler ile nasıl ilişkili olduğunun araştırılmasının, evlilik ilişkisinde iyilik hali ve psikolojik sağlık için belirleyici değişkenlerin daha iyi anlaşılmasına katkı sağlayacağı düşünülmektedir. 
Evlilik doyumunun arttrrılması, sadece aile sisteminin kendi içindeki işlevselliğini değil, aynı zamanda ailenin dışarı ile olan ilişkilerini etkilemesi açısından da önemli bir etkendir (Fışıloğlu 1992). $\mathrm{Bu}$ açıdan, evlilik doyumu düzeylerini etkileyen çoklu değişkenlerin ele alınması önemli görünmektedir. $\mathrm{Bu}$ değişkenlerden biri olarak, yaşanılan yerin ve ayrıca, evlilik doyumunu açıklamada önemli bir bilişsel değişken olan erken dönem uyum bozucu şemaların araştırılmasının anlamlı olduğu düşünülmektedir. Buna karşın, alan yazın incelendiğinde, çiftlerin yaşadıkları yerin, evlilik doyumu üzerindeki ve erken dönem uyum bozucu şemalardaki rolünü inceleyen bir araştırmaya rastlanmamıştır. Bu kapsamda, bu çalışmanın temel amacı kırda ve kentte yaşayan evli bireylerin evlilik doyumunun ve erken dönem uyumsuz şemalarının değerlendirilmesidir. Bu çalışmada evlilikte doyumun uyum bozucu şemalar gibi bilişsel değişkenlerden nasıl etkilendiği saptanarak bireylerin evlilik kalitelerini arttırmada ipuçları elde etmelerinin de sağlanacağı öngörülmektedir.

\section{Yöntem}

\section{Örneklem}

Mevcut çalışmada, 268 evli birey yer almıştır. Bireylere çift olarak ulaşılmıştır. Diğer bir deyişle, 134 evli kadın ve 134 evli erkek çalışma örneklemini oluşturmuştur. Katılımcıların 80'ine Ankara $(n=$ 40 Karadegik köyü, $n=40$ Çankaya ilçesi), 100'üne Manisa ( $n=50$ Avdan köyü, $n=50$ Merkez ilçesi) ve $88^{\prime}$ 'ine Kırıkkale ( $n=30$ Ulaş köyü, $n=58$ Merkez ilçesi) illerinde ulaşılmıştır.

Toplam örneklem için yaş 18-70 aralığındadır. Ortalama yaş toplam örneklem için $41.76(S=9.70)$; kadınlar için $39.92(S=9.21)$ ve erkekler için $43.61(S=9.85)$ olarak bulunmuştur. Kent örneklemindeki katılımcıların ortalama yaşı $40.54(S=8.43)$, kır örneklemindekilerin ortalama yaşı ise 43.27 ( $S=10.89$ ) olarak saptanmıştır. 
Katılımcıların sosyodemografik özellikleri ve evlilikleri ile ilgili değişkenleri ile ilgili bilgiler bulgularda özetlenmektedir.

\section{Veri Toplama Araçları}

Young Șema Ölçeği- Kısa Form 3 (YŞÖ-KF3). Young ve meslektaşları $(1990 ; 2003)$ tarafindan, erken dönem uyum bozucu şemaların değerlendirilmesi için geliştirilmiştir. 90 maddeden oluşan formda katılımcılar, her bir maddeyi 6'lı Likert ölçeği üzerinde $(1=$ "Benim için tamamıla yanlış", $6=$ "Beni mükemmel şekilde tanımlıyor") derecelendirmektedir. Ölçeğin özgün formunda her alt ölçek 5 maddeden (ör. "İşleri halletmede son derece yetersizim") oluşmakta, buna göre alt ölçeklerden alınan puanlar 5 ile 30 arasında değişebilmektedir (Young vd. 2003). Ölçeğin k1sa formunun ülkemizdeki geçerlik güvenirlik çalışması üniversite örnekleminde, Soygüt, Karaosmanoğlu ve Çakır (2009) tarafından yürütülmüştür. Ölçeğin Türkçe formu için beş şema alanına ulaşılmış ve 14 faktörlü bir yapının (14 şema boyutu) uygun olduğu görülmüştür. Bu beş alan ve boyutlar şu şekildedir: kopukluk (duygusal yoksunluk, sosyal izolasyon / güvensizlik, duyguları bastırma, kusurluluk); zedelenmiş otonomi (iç içe geçme / bağımlılık, terk edilme, başarısızlık, karamsarlık, tehditler karşısında dayanıksızlık); zedelenmiş sınırlar (ayrıcalıklılık / yetersiz özdenetim); diğerleri yönelimlilik (kendini feda, cezalandırılma) ve yüksek standartlar (yüksek standartlar, onay arayıcılık). Bu yapıya göre madde sayısının dağılımı değişmekle beraber toplam madde sayısı yine 90 olarak kalmıştır. Ölçeğin şema boyutları için Cronbach $\alpha$ iç tutarlılık katsayıları .63-.80 arasında; şema alanları için ise, .53-.81 arasında değişmektedir. Ölçeğin test tekrar test güvenirliği şema alanları için $r=$ $.66-.83(p<.01)$, şema boyutları için ise $r=.66-.82(p<.01)$ arasında değişmektedir (Soygüt vd. 2009). Mevcut çalışmada, 14 şema boyutu için Cronbach $\alpha$ iç tutarlılık katsayıları .52-.82 aralığında bulunmuştur. 
Çift Uyum Ölçeği (CUÖ). ÇUÖ, Spainer (1976) tarafından geliştirilmiş, ilişki niteliğini değerlendiren 32 maddelik bir ölçektir. Ölçek; çift uyumu, çift doyumu, sevgi gösterme ve çiftlerin bağlıllğı alt ölçeklerinden oluşmaktadır. ÇUÖ, 5'li, 6'lı ve 7'li Likert tipi ölçek üzerinde puanlanan maddeler (ör. "Ne sıklıkla siz veya eşiniz kavgadan sonra evi terk edersiniz?") içermektedir. Ayrıca "Evet" veya "Hayır" olarak cevaplanan maddeler bulunmaktadır. Toplam puan bütün maddeler için 0'dan 151'e doğru uzanmaktadır. Yüksek puanlar ilişkinin niteliğine dair algının yüksek olduğunu yansıtmaktadır. Spanier'ın (1976) geliştirdiğgi özgün ölçeğin güvenilirlik katsayıları toplam ölçek için .96; alt ölçeklerde çift uyumu için .90, çift doyum için .94, çiftlerin bağl1lı̆̆ 1 için .86 ve sevgi gösterme için .73 olarak hesaplanmıştır. Ölçeğin Türkçe formu Fışıloğlu ve Demir (2000) tarafindan uyarlanmıştır. Türkçe formun iç tutarlılık katsayısı .90 olarak hesaplanmıştır. Mevcut çalışmada ise, toplam ölçek için Cronbach $\alpha$ iç tutarlılık katsayısı .91 olarak hesaplanmıştır.

Yukarıdaki iki ölçüm aracına ek olarak, katılımcılardan bir demografik bilgi formunu doldurmaları da istenmiştir. Bilgi toplama formu araştırmacılar tarafından geliştirilmiştir ve çalışmaya katılan çiftin cinsiyeti, yaşı, eğitim düzeyi, çalışma durumu, kaç yıldır evli olduğu, eşi ile yaş farkı, evlenme biçimi, çocuk sayısı, evlilik yaşı ve gelir düzeyi gibi bilgileri içermektedir.

\section{İşlem}

Çalışma öncesinde, TOBB Ekonomi ve Teknoloji Üniversitesi İnsan Araştırmaları Değerlendirme Kurulundan etik onay alınmıştır. Formlar, katılımcılara araştırmacılar tarafından elden dağıtılmıştır. Formlar kapalı zarf içinde verilmiş; zarfların önüne, çalışma hakkında bilgi ve gönüllü katılım kapsamında çalışmadan ayrılma ve gizlilik haklarını belirten bir onam formu ayrıca eklenmiştir. Katılımcı çiftlerden kendilerine dağıtılan formları ayrı ayrı doldurmaları 
istenmiştir. Katılımcıların seçildiği kırsal ve kentsel alanlar belirlenirken, Türk Dil Kurumu Sözlükleri içeriğindeki tanımlar dikkate alınmıştır. Türk Dil Kurumu kırsalı "az insanın barındığı, genellikle kır durumunda olan yer" (Güncel Türkçe Sözlük 2019a); kenti / şehri ise "nüfusunun çoğu ticaret, sanayi, hizmet veya yönetimle ilgili işlerle uğraşan, genellikle tarımsal etkinliklerin olmadığı yerleşim alanı" (Güncel Türkçe Sözlük 2019b) olarak tanımlanmaktadır. Bu tanımlar temelinde, kırdaki katılımcılara köylerde; kentteki katılımcılara ise şehirlerin merkez ilçelerinde ulaşılmıştır. Katılımcılar kota örneklemesi yoluyla çalışmaya dâhil edilmiştir. Ardından, her kotadaki katılımcılara uygun örnekleme yoluyla ulaşılmıştır. Çalışmanın örneklemi kırsal ve kentsel bölgelerde yaşayan kadın ve erkeklerin eşit olarak temsil edilmesi amaciyla düzenlenmiştir.

\section{Bulgular}

\section{Örneklemin Sosyodemografik Özellikleri}

Betimleyici istatistikler kullanılarak, katılımcıların sosyodemografik özellikleri ve evlilik değişkenleri değerlendirilmiştir. Kentsel ya da kırsal bölgelerde yaşayan evli bireylerin sosyodemografik özellikleri ile evlilik ilişkilerine dair özellikler Tablo 1 ve 2'de gösterilmektedir.

Eşler arası yaş farkı, çocuk sayısı, evlilik süresi ve evlenme yaşını içeren sürekli değişkenler t-testi kullanılarak incelendiğinde, kentte yaşayanların kırsaldakilere kıyasla eşler arası yaş farkının ve çocuk sayısının daha az olduğu görülmüştür. Bununla birlikte, evlenme yaşının kırsalda yaşayanlarda kentte yaşayanlara kıyasla daha küçük olduğu bulunmuştur. 
Tablo 1: Kentsel ya da Kırsal Bölgelerde Yaşayanların Sosyodemografik Özelliklerinin Sürekli Değerlerinin Karşılaştırılması

\begin{tabular}{|c|c|c|c|c|}
\hline Değişken & Grup & Ort. & $S$ & $t$ \\
\hline \multirow{2}{*}{$\begin{array}{l}\text { Eşler arası yaş fark1 } \\
\text { (Erkek-Kadın) }\end{array}$} & Kentsel & 3.47 & 3.02 & \multirow[t]{2}{*}{-1.31} \\
\hline & Kırsal & 3.94 & 2.72 & \\
\hline \multirow{2}{*}{ Çocuk sayısı } & Kentsel & 1.60 & 0.95 & \multirow[t]{2}{*}{$-6.21^{* *}$} \\
\hline & Kırsal & 2.30 & 0.84 & \\
\hline \multirow[t]{2}{*}{ Evlilik süresi (Y1l) } & Kentsel & 15.29 & 9.50 & \multirow[t]{2}{*}{$-5.05^{* *}$} \\
\hline & Kırsal & 21.83 & 11.65 & \\
\hline \multirow[t]{2}{*}{ Evlenme yaşı } & Kentsel & 24.95 & 5.22 & \multirow[t]{2}{*}{$5.97^{*}$} \\
\hline & Kırsal & 21.53 & 3.86 & \\
\hline
\end{tabular}

${ }^{* *} p<.001, \stackrel{*}{p} p<.05$.

Eğitim düzeyi, çalışma durumu, gelir düzeyi ve evlenme biçimini içeren kategorik değişkenlerin normal olmayan dağılımları göz önünde bulundurularak, kırdaki ve kentteki katılımciların bu değişkenlerdeki özelliklerini incelemek amacıyla bağımsız örneklemler Kruskal Wallis-H testi uygulanmıştır. Analizler, kırda ya da kentte yaşayan evli bireylerin tüm değişkenlerdeki sıklığının anlamlı olarak farklı olduğu bulunmuştur $(p<.001)$. Buna göre, kırsalda yaşayanlara kıyasla, kentte yaşayanların daha sıklıkla yüksekokul ve üstü düzeyde eğitim düzeyine sahip oldukları görülmüştür. Kırsalda yaşayanlar daha sıklıkla ilkokul ya da ortaokul düzeyinde eğitime sahip bulunmuştur. Ayrıca, kentte yaşayanların daha fazla çalışma eğiliminde olduğu saptanmıştır. Orta gelir düzeyinde gruplar arası fark bulunmazken, kenttekilerin daha büyük bir bölümünün yüksek; kirsaldaki katılımcıların daha büyük bir bölümünün ise düşük gelir düzeyine sahip olduğu görülmüştür. Evliliğini kendi anlaşarak / severek yaptığını belirtenlerin oranı kentte daha yüksekken; görücü usulü evlendiğini belirtenlerin oranı kırsalda daha yüksek bulunmuştur. Bulgular Tablo 2'de gösterilmektedir. 
Tablo 2: Kentsel ya da Kırsal Bölgelerde Yaşayanların Sosyodemografik Özelliklerinin Kategorik Değerlerinin Karşılaş̧tırılması

\begin{tabular}{|c|c|c|c|c|c|}
\hline \multirow{2}{*}{$\begin{array}{l}\text { Değişken } \\
\text { Eğitim } \\
\text { düzeyi }\end{array}$} & Düzey & Grup & Siklık & $\%$ & $\chi^{2}$ \\
\hline & $\begin{array}{l}\text { İlkokul } \\
\text { Ortaokul } \\
\text { Lise } \\
\text { Yüksekokul } \\
\text { Lisans } \\
\text { Lisansüstü }\end{array}$ & $\begin{array}{l}\text { Kentsel } \\
\text { Kırsal } \\
\text { Kentsel } \\
\text { Kırsal } \\
\text { Kentsel } \\
\text { Kırsal } \\
\text { Kentsel } \\
\text { Kursal } \\
\text { Kentsel } \\
\text { Kursal } \\
\text { Kentsel } \\
\text { Kursal } \\
\text { Kentsel } \\
\text { Kursal }\end{array}$ & $\begin{array}{c}11_{\mathrm{a}} \\
2 \mathrm{a} \\
99_{\mathrm{a}} \\
45_{\mathrm{b}} \\
99_{\mathrm{a}} \\
23_{\mathrm{b}} \\
48_{\mathrm{a}} \\
36_{\mathrm{a}} \\
19_{\mathrm{a}} \\
6_{\mathrm{b}} \\
47_{\mathrm{a}} \\
8_{\mathrm{b}} \\
15_{\mathrm{a}} \\
0_{\mathrm{b}}\end{array}$ & $\begin{array}{c}0.4 \\
0.7 \\
3.4 \\
16.8 \\
3.4 \\
8.6 \\
17.9 \\
13.4 \\
7.1 \\
2.2 \\
17.5 \\
3.0 \\
5.6 \\
0.0 \\
\end{array}$ & 77.55 \\
\hline Çalışma du & $\begin{array}{l}\text { mu } \\
\text { Çalışmıyor } \\
\text { Çalışıyor }\end{array}$ & $\begin{array}{l}\text { Kentsel } \\
\text { Kursal } \\
\text { Kentsel } \\
\text { Kursal } \\
\end{array}$ & $\begin{array}{c}27_{\mathrm{a}} \\
59_{\mathrm{b}} \\
121_{\mathrm{a}} \\
61_{\mathrm{b}} \\
\end{array}$ & $\begin{array}{l}10.1 \\
21.0 \\
45.1 \\
22.8 \\
\end{array}$ & 28.97 \\
\hline $\begin{array}{l}\text { Gelir } \\
\text { düzeyi }\end{array}$ & $\begin{array}{l}\text { Düşük } \\
\text { Orta }\end{array}$ & $\begin{array}{l}\text { Kentsel } \\
\text { Kursal } \\
\text { Kentsel } \\
\text { Kırsal } \\
\text { Kentsel } \\
\text { Kırsal }\end{array}$ & $\begin{array}{c}44_{\mathrm{a}} \\
15_{\mathrm{b}} \\
110_{\mathrm{a}} \\
93_{\mathrm{a}} \\
34_{\mathrm{a}} \\
12_{\mathrm{b}} \\
\end{array}$ & $\begin{array}{c}1.5 \\
5.6 \\
41.0 \\
34.7 \\
12.7 \\
4.5 \\
\end{array}$ & 14.39 \\
\hline Evlenme bi & $\begin{array}{l}\text { mi } \\
\text { Kendi anlaşarak } \\
\text { severek } \\
\text { Görücü usulü }\end{array}$ & $\begin{array}{l}\text { Kentsel } \\
\text { Kırsal } \\
\text { Kentsel } \\
\text { Kırsal } \\
\end{array}$ & $\begin{array}{l}96_{\mathrm{a}} \\
42_{\mathrm{b}} \\
50_{\mathrm{a}} \\
78_{\mathrm{b}}\end{array}$ & $\begin{array}{l}36.1 \\
15.8 \\
18.8 \\
23.3 \\
\end{array}$ & 24.86 \\
\hline
\end{tabular}

${ }^{* *} p<.001$. 
Not: Her düzey için aynı sıradaki farklı alt simgeler ( ${ }^{\mathrm{a}}$ ya da $\left.{ }^{\mathrm{b}}\right)$ sıklığın anlamlı olarak farklı olduğuna işaret etmektedir.

\section{Farkları}

\section{Çalışma Değişkenlerinde Yaşanılan Yere Göre Grup}

Kentte ya da kırda yaşayan evli bireylerde temel çalışma değişkenlerinin karşılaştırılması amacıyla, bir dizi çoklu bağımsız örneklemler t-testi analizleri gerçekleştirilmiştir. Buna göre, yaşanılan yer bağımsız değişken; evlilik doyumunun alt boyutlarındaki puanlar ile toplum doyum puanı ve erken dönem uyum bozucu şema puanları bağımlı değişken olarak analize katılmıştır.

İlk olarak, kentte ya da kırsalda yaşayan evli bireylerin evlilik doyumu puanları incelenmiştir. Buna göre, kırsalda yaşayanların toplam evlilik doyumu puanları ile evlilik doyumunun alt boyutları olan sevgi gösterme, çift uyumu ve çift doyumu puanları kentte yaşayanların toplam evlilik doyumu, sevgi gösterme, çift uyumu ve çift doyumu puanlarına kıyasla $p<.01$ düzeyinde anlamlı olarak daha yüksek bulunmuştur. İkinci olarak, kentte ya da kırsalda yaşayan evli bireylerin erken dönem uyum bozucu şema alanlarındaki puanları incelendiğinde, kırsalda yaşayanların altı şema alanındaki (duyguları bastırma, onay arayıc1lık, kendini feda, cezalandırılma, dayanıksızlık ve yüksek standartlar) puanının kentte yaşayanlara kıyasla $p<.01$ ila $p<.001$ düzeylerinde anlamlı olarak daha yüksek olduğu görülmüştür. Örneklemlerin ortalama ve standart sapma değerleri ile grup karşılaştırmasına yönelik t-testi bulguları Tablo 3 'te gösterilmektedir. 
Tablo 3: Kentte ya da Kırsalda Yaşayan Evli Bireylerde Temel Çalışma Değişkenlerinin Karşılaştırılması

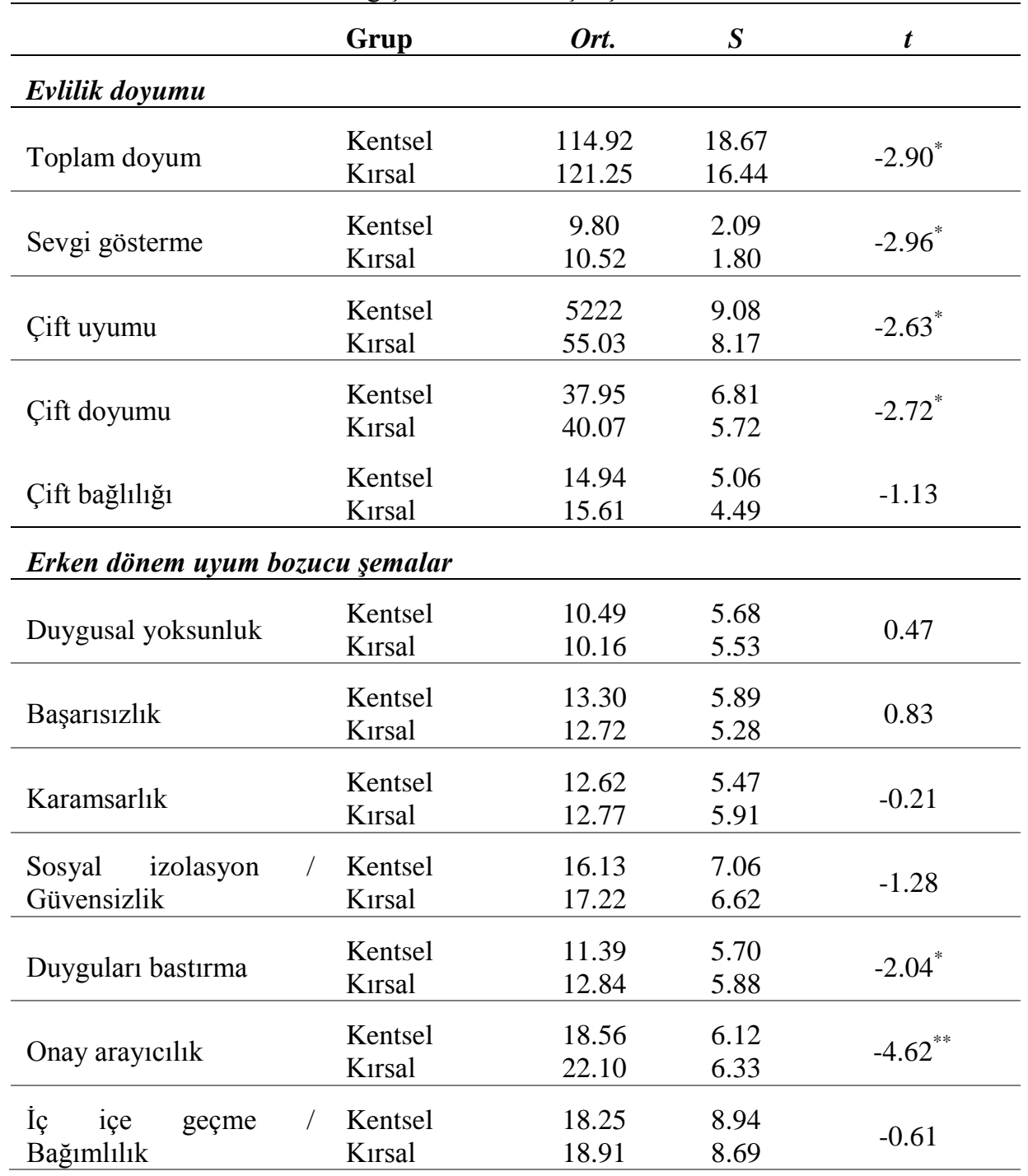

Uludağ Üniversitesi Fen-Edebiyat Fakültesi Sosyal Bilimler Dergisi Uludağ University Faculty of Arts and Sciences Journal of Social Sciences Cilt: 21 Sayl: 38 / Volume: 21 Issue: 38 


\begin{tabular}{|c|c|c|c|c|}
\hline $\begin{array}{l}\text { Ayrıcalıklılık } \\
\text { Yetersiz özdenetim }\end{array}$ & $\begin{array}{ll}\text { / Kentsel } \\
\text { Kirsal } \\
\end{array}$ & $\begin{array}{l}22.36 \\
24.59 \\
\end{array}$ & $\begin{array}{l}6.35 \\
6.43 \\
\end{array}$ & -2.83 \\
\hline Kendini feda & $\begin{array}{l}\text { Kentsel } \\
\text { Kırsal }\end{array}$ & $\begin{array}{l}15.90 \\
19.34 \\
\end{array}$ & $\begin{array}{l}5.58 \\
5.19 \\
\end{array}$ & $-5.16^{* *}$ \\
\hline Terk edilme & $\begin{array}{l}\text { Kentsel } \\
\text { Kirsal }\end{array}$ & $\begin{array}{c}10.30 \\
9.94 \\
\end{array}$ & $\begin{array}{l}5.50 \\
5.18 \\
\end{array}$ & 0.55 \\
\hline Cezalandirılma & $\begin{array}{l}\text { Kentsel } \\
\text { Kirsal }\end{array}$ & $\begin{array}{l}19.80 \\
24.05\end{array}$ & $\begin{array}{l}6.38 \\
6.23 \\
\end{array}$ & $-5.48^{* * *}$ \\
\hline Dayanıksızlık & $\begin{array}{l}\text { Kentsel } \\
\text { Kirsal }\end{array}$ & $\begin{array}{l}12.14 \\
14.17 \\
\end{array}$ & $\begin{array}{l}4.85 \\
5.62 \\
\end{array}$ & $-3.16^{* *}$ \\
\hline Yüksek standartlar & $\begin{array}{l}\text { Kentsel } \\
\text { Kirsal }\end{array}$ & $\begin{array}{c}8.99 \\
10.75 \\
\end{array}$ & $\begin{array}{l}3.76 \\
4.21 \\
\end{array}$ & $-3.61^{* *}$ \\
\hline Kusurluluk & $\begin{array}{l}\text { Kentsel } \\
\text { Kırsal }\end{array}$ & $\begin{array}{l}11.41 \\
10.74\end{array}$ & $\begin{array}{l}6.57 \\
5.69\end{array}$ & 0.87 \\
\hline
\end{tabular}

${ }^{* *} p<.001, \stackrel{*}{p}<<.01$.

\section{Sosyodemografik Özelliklerin, Evlilik Değişkenlerinin ve} Erken Dönem Uyum Bozucu Şemaların Evlilik Doyumu Üzerindeki Yordayıcı Etkisi

Çalışmanın amaçları doğrultusunda, evlilik doyumunu yordayan değişkenleri saptayabilmek adına kırda ya da kentte yaşayan evli bireyler için ayrı iki doğrusal çoklu regresyon analizi yapılmıştır. Regresyon analizlerinde birinci adımda eşitliğe sosyodemografik değişkenler (cinsiyet, yaş, eğitim düzeyi, çalışma durumu, gelir düzeyi); ikinci adımda evlilik değişkenleri (evlilik süresi, evlenme yaşı, eşler arası yaş farkı, çocuk sayısı, evlenme biçimi); son aşamada ise erken dönem uyum bozucu şemalar girilmiştir. Yapılan regresyon analizlerinde, toplam evlilik doyumu puanı bağımlı değişken olarak kullanılmıştır. 
Kent örnekleminde yapılan regresyon analizinin bulguları incelendiğinde, birinci adımdaki sosyodemografik değişkenlerin evlilik doyumu puanını anlamlı olarak yordamadığ 1 görülmüştür $(F[5,145]=$ $\left.0.96, p>.05, R^{2}=.03\right)$. İkinci adımda, benzer şekilde, evlilik değişkenlerinin de evlilik doyumunu anlamlı olarak açıklamadığ görülmüştür $\left(F[10,145]=1.23, p>.05, R^{2}=.08\right)$. Erken dönem uyum bozucu şemaların dâhil olduğu üçüncü adımda, şemaların evlilik doyumundaki varyansın ek olarak \%26'sını açıkladığı görülmüştür $\left(F[24,145]=2.40, p \leq .001, R^{2}=.32\right)$. Bu adımda, duygusal yoksunluk $(\beta=-.49, t=-3.78, p<.001)$ ve sosyal izolasyon / güvensizlik $(\beta=-.30$, $t=-2.59, p<.05)$ alanlarındaki şema puanları evlilik doyumu ile beklendik yönde ilişkili bulunmuştur. Tüm değişkenler eşitlikteyken, değişkenlerin evlilik doyumundaki varyansın \%36'sını açıklandığı görülmüştür.

Kırsalda yaşayan evli bireyleri içeren örneklemde gerçekleştirilen regresyon analizinde ise, birinci adımdaki sosyodemografik değişkenlerin evlilik doyumu puanını anlamlı olarak yordamadığı görülmüştür $\left(F[5,114]=1.75, p>.05, R^{2}=.07\right)$. İkinci adımda, evlilik değişkenlerinin evlilik doyumunu anlamlı olarak açıkladığı görülmüştür $\left(F[10,109]=2.03, p<.05, R^{2}=.16\right) . \mathrm{Bu}$ adımda, çocuk sayısı $(\beta=-.26, t=-2.29, p<.05)$ evlilik doyumu ile ilişkili bulunmuştur. Erken dönem uyum bozucu şemaların dâhil olduğu üçüncü adımda, şemaların evlilik doyumundaki varyansın ek olarak \%20'sini açıkladığı görülmüştür $\left(F[24,95]=2.21, p<.01, R^{2}=.36\right)$. Bu adımda, duygusal yoksunluk $(\beta=-.28, t=-2.03, p<.05)$, başarısızlık $(\beta$ $=.27, t=2.14, p<.05)$, cezalandırılma $(\beta=.29, t=2.77, p<.01) \mathrm{ve}$ dayanıksılık $(\beta=.22, t=2.06, p<.05)$ şema puanları evlilik doyumu ile ilişkili bulunmuştur. Tüm değişkenler eşitlikteyken, değişkenlerin evlilik doyumundaki varyansın \%36'sını açıklandığı görülmüştür. 


\section{Tartışma}

$\mathrm{Bu}$ çalışmanın temel amacı, yaşanılan yerin ve erken dönem uyum bozucu şemaların evlilik doyumu üzerindeki etkisini incelemektir. Önceki çalışmalarda, erken dönem uyum bozucu şemalar, yaşanılan yer ve evlilik doyumu değişkenlerinin birlikte ele alınmadığ görülmektedir. Her ne kadar daha önce kırda ya da kentte yaşayan kadınların evlilik doyumunu karşılaştıran bir çalışma mevcut olsa da (bk. Kaya 2017), bu çalışma sözü edilen üç değişkenin bir arada ele alınması ve erkeklerin de örnekleme dâhil edilmesi açısından alan yazında bilindiği kadarıyla ilktir.

Çalışma bulguları, kırsal bölgelerde yaşayan evlilerin genel evlilik doyum düzeylerinin kentte yaşayan evli bireylere göre anlamlı olarak daha yüksek olduğunu göstermiştir. Bu fark, özellikle çift uyumu, çift doyumu ve sevgi gösterme alt boyutlarında belirgin görülmüştür. Kırsal ya da kentsel bölgelerde yaşamanın evlilik doyumu üzerindeki etkisini inceleyen çalışma sayısı oldukça azdır. Örneğin, Lamke (1989) araştırmasında kırsalda yaşayan çiftlerin evlilik doyumunda eşlerin kendilerini dışa vurmasının rolünü incelemiştir. Bununla birlikte, kırsalda yaşayanların evlilik doyum düzeylerinin kentte yaşayanlarınkine yönelik bir kıyaslama sunmamıştır. Diğer bir çalışmada, Kore'de kente göç eden kadınlar ile kırsalda yaşayan kadınların evlilik doyumları karşılaştırılarak şehirde yaşayan evli kadınların daha yüksek evlilik doyumları olduğu bulunmuştur (Nam vd. 2011). Önceki bu çalışmada ise örnekleme erkek katılımcıların dâhil edilmemiş olmasından dolayı doyum düzeylerinin farklı çıkmış olması mümkündür. Bununla birlikte, her ne kadar çalışmaya erkekler dâhil edilmemiş olsa da Türkiye'de daha önce kırda yaşayan kadınların evlilik doyumu düzeyinin kentte yaşayanlardan daha yüksek olduğu gösterilmiştir (Kaya 2017). Ayrıca, yaşam doyumunun kırda yaşayan insanlarda kentte yaşayan insanlara göre anlamlı derecede yüksek 
olduğu bildirilmektedir (Sorensen 2014). Yaşam doyumu, bilişsel bir kavramdır ve bireyler yaşam doyumunu belirlenen dışsal hedefler yerine içsel standartları temelinde değerlendirme eğilimindedir (Diener vd. 1985). Evlilik doyumunun da şemalar dâhil olmak üzere çeşitli bilişsel etkenlerden etkilendiği düşünüldüğünde, genel evlilik doyumunun (ve sözü edilen alt boyutlarının) genel yaşam doyumu ile ilişkili olması ve mevcut çalışmanın bulgularının bu türdeki daha genel bir doyumu yansitıyor olması olasıdır. Bununla birlikte, evlilik doyumunun dördüncü boyutu olan çiftin birbirine bağlılık düzeyleri mevcut çalışmada yaşanılan yere göre değişim göstermemiştir. Yetişkinlik döneminde romantik ilişkinin yaşandığ1 kişilere karş1 bağlanma diğer kişilere olduğundan daha baskındır (Morsünbül vd. 2011). Çalışmada kırda ve kentteki katılımcıların eşlerine bağlılık düzeyleri arasında anlamlı fark olmamasının, kişiler arası ilişkilerde bağlılığın temel bir ihtiyaç olması ve yaşanılan yere göre değişmiyor olabileceği ile açıklanması mümkündür. Kişinin yakın ilişki içinde olduğu kişiler ile uyumlu ve güçlü ilişkiler içinde olması dengeli benliğe ulaşmada önemli bir ön koşuldur (İmamoğlu 1994).

Kentte ya da kırda yaşayan evli bireylerin şema puanları incelendiğinde, duyguları bastırma, onay arayıcılık, kendini feda, cezalandırılma, dayanıksızlık ve yüksek standartlar şemalarında kırda yaşayanların kentte yaşayanlara kıyasla daha yüksek puanlar aldıkları görülmüştür. Duyguları bastırma, kopukluk; yüksek standartlar ve onay arayıcılık, yüksek standartlar; kendini feda ve cezalandırılma, diğerleri yönelimlilik; dayanıksızlık ise zedelenmiş otonomi şema alanları ile ilişkilidir. Bu açıdan, kentsel ve kırsal bölgelerde puan farkı bulunan şema boyutları zedelenmiş sınırlar hariç tüm şema alanları ile ilgilidir. Böylece, uyum bozucu şemaların bilişsel bir bakış açısından incinebilirliği artırdığg düşünüldüğünde (Tilden vd. 2005), kırdaki evli bireylerin bireysel incinebilirlik düzeylerinin daha yüksek olduğu görülmektedir. $\mathrm{Bu}$ incinebilirlik kısmen bireysel özelliklerden 
kaynaklıyor olabileceği gibi; kısmen de kırsal bölgede yaşama ile ilgili olabilir. Kırsal bölgelerin uzaklığı bazen bireylerin yalıtılmış olmalarına; sosyal destek ağlarına yeterince dâhil olamamalarına, yeterli maddi kazanç getiren işlerin ve serbest zaman etkinliklerinin kısıtlı olmasına neden olmaktadır (Edgerton 1983). Kırsal bölgelerde bireylerin birçok açıdan incinebilir olabileceği göz önünde bulundurularak toplum ruh sağlığı müdahaleleri ya da sosyal politikalar geliştirilirken bu gruba odaklanmak özellikle önemli görünmektedir.

Temel analizlerde, ilk olarak, evlilik doyumu ile cinsiyet, yaş, eğitim düzeyi, çalışma biçimi ve gelir düzeyini içeren demografik değişkenlerin ilişkisi incelendiğinde, bu değişkenlerin hiçbirinin kentsel ve kırsal bölgelerden alınan örneklemlerde evlilik doyumunu yordamadığı görülmüştür. Alan yazındaki bazı diğer çalışmalar da bu bulguyu destekler niteliktedir. Örneğin, yaş, cinsiyet, ev işlerini üstlenme, evlilik yılı, çocuk sayısı, iş ve eğitim düzeyleri gibi demografik değişkenlerin evlilik uyumu üzerindeki etkisinin araştırıldı̆̆ 1 bir çalışmada bu değişkenlerin evlilik uyumu ile ilişkili olmadığı bulunmuştur (Tutarel Kışlak vd. 2002). Bununla birlikte, Tezer (1994) ve Yalçın (2014) araştırmalarında evlilik doyumunu yordayan tek demografik değişkenin yaş olduğunu bulmuşlardır. Bu açıdan, alan yazında demografik değişkenlerin evlilik doyumu ile ilişkisi konusunda karmaşık bulgular bulunmaktadır. Gelecek araştırmalarda, yaşanılan yer gibi toplumsal özellikler de göz önünde bulundurularak, demografik özelliklerin evlilik doyumu ile ilişkisinin farklı örneklemlerde incelenmesinin yararlı olabileceği düşünülmektedir.

Evlilik değişkenleri ile ilgili olarak, kır örneklemindeki bulgular incelendiğinde, hanedeki çocuk sayısı arttıkça genel evlilik doyumu düzeyinin azaldığı görülmüştür. Arslan ve Arslan (2015), kırsal bölgelerde zaman içinde çocuğun ekonomik değeri yerine, sosyal ve 
psikolojik değerinin daha ön plana çıkmaya başladığını; bu nedenle de, hanedeki her ilave nüfusun ciddi bir maddi yük getirdiğini belirtmiştir. Çiftler önceki dönemlere kıyasla daha az çocuk yapma eğiliminde olmaya ve böylece, kır nüfusu da yaşlanmaya başlamıştır. Bu yaşlanma eğilimi, mevcut çalışmadaki örneklemler arası yaş farkıyla da uyumludur. Böylece, çocuğun maddi yükü nedeniyle kırsal bölgelerde çocuk sayısı ile birlikte evlilik doyumunun azalması olasıdır. Ayrıca, çocuk sahibi olmanın evliliğin yapısında değişimlere neden olduğu; ebeveynler arasında etkileşimin azaldığı ve evlilikte görev dağılımının daha geleneksel hale geldiği belirtilmiştir (White vd. 1986). Mevcut çalışmada, ayrıca, çocuk sayısı kentte evlilik doyumunu yordamamıştır. Miller (1976) eşlerin eğitim düzeyi ve mesleki statüsü yükseldikçe, çocuk sayısından bağımsız olarak, eşlerin birlikte yaptıkları etkinliklerin arttığını; özellikle sosyal sınıfı daha düşük ailelerde eşlerin birbirine eşlik ettiği etkinliklerin sayısının aşırı az olduğunu belirtmiştir. Bunun, eğitim ve gelir düzeyinin daha yüksek olduğu kent örnekleminde çocuk sayısı ve evlilik doyumu açısından ilişki bulunmamasını açıklaması olasıdır.

Temel analizlerde, ayrıca, kentte ya da kırda yaşayan iki grupta evlilik doyumunu etkileyen erken dönem uyum bozucu şemaların duygusal yoksunluk şeması haricinde farklılık gösterdiği bulunmuştur. Kentte evlilikteki toplam doyum puanlarını sosyal izolasyon / güvensizlik ve duygusal yoksunluk şemaları yordarken; kırsalda toplam doyumu duygusal yoksunluk, başarısızlık, cezalandırılma ve dayanıksızlık şemalarının yordadığ bulunmuştur. Kent örnekleminde, duygusal yoksunluk ve sosyal izolasyon / güvensizlik şema puanları arttıkça evlilik doyumunun düştüğü görülmüştür. Bu yöndeki bir ilişki, kırsal örneklemde duygusal yoksunluk şeması için de geçerli bulunmuştur. Young ve arkadaşlarına (2003) göre, duygusal yoksunluk, kişinin duygusal destek arzusunun başkaları tarafından yeterince karşılanmayacağı beklentisidir ve ilgi, empati ya da korunma 
yoksunluğu biçiminde görülebilmektedir. YŞÖ-KF3'ün Türkçe formunun oluşturulması sirasinda (bk. Soygüt vd. 2009) sosyal izolasyon / yabancılaşma ile güvensizlik / suistismal edilme şemalarının birleştirilmesi ile oluşturulan sosyal izolasyon / güvensizlik ise, ait olmama, yalnızlık, güvensizlik ve başkaları tarafından kullanılmış hissetme ile karakterizedir. Duygusal yoksunluk ve sosyal izolasyon/güvensizlik şemalarının ilişki doyumundaki düşüklük ile ilişkili olduğu bulgusu, daha önce romantik ilişkilerde erken dönem uyum bozucu şemaları inceleyen çalışmalarda yinelenmiştir (ör. Dumitrescu vd. 2012; Esmaili vd. 2016; Soysal 2017). Bu şemalar, kişilerin mesafeli, yeterince ilgili olmayan eş seçimine neden olabileceği gibi; bunların evlilik ilişkisi içinde kendini ait ya da güvende hissetmemeye, eşinden izole ya da farklı hissetmeye, kişinin eşinden ilgi ya da empati talep etmekte yetersiz kalmasına da neden olabileceği düşünülmektedir.

Analizlerde, dikkat çekici olarak, kırsal örneklemde başarısızlık, cezalandırılma ve dayanıksızlık şema alanlarındaki puanlar arttıkça, evlilik doyumunun da arttığı görülmüştür. Diğer bir deyişle, sözü edilen şemalara sahip evli bireylerde, bildirilen evlilik doyumu daha yüksektir. Başarısızlık, cezalandırılma ve dayanıksızlık şemalarında "İşleri halledebilmekte yetersizim", "Ne kadar çok çalışırsam çalışayım iflas edebilirim", "Hatalarım karşısında cezalandırılmalıyım" gibi kişinin kendine atıflar yaptığı düşünceler hâkimdir (Young 1999). Özellikle başarısızlık ve dayanıksızlık şemaları, zedelenmiş özerklik şema alanı altındadır ve kişinin bağımsız hareket edebilme, yaşam becerileri kazanma ve kimlik oluşturma ile çatışan beklentilerine sahip olması ile ilgilidir (Young vd. 2003). Ayrıca, kişi herhangi bir anda felaket olacağına ve ondan korunmayacak olduğuna dair korkuya ve başkalarından daha az başarılı, becerikli, akıllı olduğuna dair inançlara sahiptir. Örneğin, dayanıksızlık şemasına sahip kişiler sürekli olarak riskli ve tehlikeli durumlardan kaçındıkları için büyük şehirlerde 
yaşamak istememektedirler (Young vd. 1994). Başarısızlık şemasına sahip kişiler ise, potansiyelinin altında meslek seçimi yapmaya yönelebilmektedir. Cezalandırılma şeması ise, kişinin hatalar için kendilerini ya da başkalarını affetme zorluğu, tüm sorumlulukların eksiksiz yerine getirilmesi gerektiği inancı ve hatalardan kaçınma ile ilgilidir. Bu açıdan kırsal bölgelerde, sözü edilen bu şemaları olanların, yaşamlarını dar sınırlar altında tutma eğiliminde olmaları olasıdır. Mevcut çalışmada kırda yaşayanların kenttekilere kıyasla daha büyük bir kısmının düşük gelir düzeyine ve daha küçük bir kısmının yüksek gelir düzeyine sahip olduğu düşünüldüğünde, yoksulluğun kırsal bölgelerde daha yaygın olduğu izlenimi edinilmektedir. Yoksulluğun kırsalda, kente kıyasla daha utanç verici görülebileceği ve yoksul kişilerin kendisini yetersiz, başarısız, damgalanmış ve farklı hissetmesine neden olabileceği belirtilmektedir (Amato vd. 1992). Bunun da, yukarıda belirtilen uyum bozucu şemaların gelişmesinde rol oynayabileceği düşünülmektedir.

Kırsal bölgelerde yaşayanlar arasında başarısızlık, cezalandırılma ve dayanıksızlık şemaları olanların daha yüksek düzeyde evlilik doyumu bildirmeleri şemayı aşırı telafi (ödünleme) kavramı ile de açıklanabilir. Bireyin engellenen temel ihtiyaçları ve gelişen şemanın yarattığı korku, bireyin çeşitli baş etme mekanizmalarından birine başvurmasını sağlamaktadır (Young vd. 2003). Bireyler uyum bozucu şemalar ile kaçınma ya da teslim olmanın yanı sıra, aşırı telafi yoluyla da baş edebilmektedir. Aşırı telafi yapan birey, şema karşıtlığı doğruymuşçasına düşünmekte, hissetmekte ve hareket etmektedir. $\mathrm{Bu}$ şekilde, birey çaresizlik ve incinebilirlikten kaçabilmektedir. Mevcut çalışmada, kırsal bölgelerde yaşayanların, diğer dört boyuta ek olarak dayanıksızlık ve cezalandırılma şema boyutlarındaki puanlarının da kenttekilere daha yüksek olduğu; diğer bir deyişle, kırsal bölgelerde yaşayan evli bireylerin 'bilişsel incinebilirlik' düzeylerinin daha yüksek olduğu gösterilmiştir. Bu türdeki bir incinebilirlikten kaçabilmek için 
uyum bozucu şemaları olan evli bireylerin ilişkilerindeki doyumu gerçekçi olmayan bir biçimde daha yüksek algılama eğiliminde bulunmuş olmaları olasıdır. Ayrıca, bu bireyler şema telafisi nedeniyle eş desteğini almaya ya da eş ile daha sı iletişim kurmaya yönelebilirler. Evlilikte iletişimin evlilik doyumunu güçlü ş̧ekilde yordadığı bilinmektedir (Litzinger vd. 2005). Eşlerin yapıcı iletişim için çabasının bireylerin evlilik doyumu düzeyini artırması beklenebilir. $\mathrm{Bu}$ bulguya yönelik başka bir açıklama da bilişsel tutarlılık kuramı ile ilgilidir. Bu kurama göre evlilik süresi uzadıkça boşanma olasılığ 1 azalmaktadır; mutsuz çiftler de bilişsel uyumsuzluğu azaltma amacıyla evliliklerini git gide daha mutlu olarak bildirme eğiliminde olmaktadır (Abelson vd. 1968). Yine de, bu bulguların daha iyi açıklanması için, gelecek çalışmalarda kırsal bölgelerde evlilik doyumu ve erken dönem uyum bozucu şemalar arasındaki ilişkinin daha ayrıntılı incelenmesinin önemli olduğu düşünülmektedir.

Mevcut çalışma Türkiye'deki üç farklı şehirden katılımcılar ile yürütülmüş̧ür. Çalışmanın sınırlılıklardan biri kent ve kırdaki örneklem büyüklüğünün eşit olmamasıdır. Her ne kadar araştırma yaparken bölgelerde ulaşılan katılımcı sayıları dengelenmeye çalışılmışsa da, kırdaki katılımcıların yanıt vermeme oranı daha yüksek olmuştur. Gelecek çalışmalarda, örneklem büyüklüğü ve dağılımı göz önünde bulundurularak, daha geniş örneklemlerin kullanıldığı; hatta çiftin analiz birimi olarak alındığı çalışmaların tasarlanması önerilmektedir. Çalışma, ayrıca, erken dönem yaşantılara ilişkin hatırlamalara ve eğitim düzeyine bağlı olarak katılımcıların ölçeklerdeki maddeleri anlayabilmeye ilişkin sınırlılıklar içermektedir. Bununla birlikte, erken dönem şemalar incelenirken, şemalar ile uyum bozucu baş etme biçimlerinin (kaçınma, aşırı telafi, teslim olma) ve tepkilerinin de önemli unsurlar olduğu bilinmektedir. Bu nedenle, evlilik bağlamında erken dönem uyum bozucu şemaların inceleneceği gelecek çalışmalarda bu unsurların da çalışmalara dâhil edilmesinin ve ayrıca, özbildirime 
dayalı ölçeklere ek olarak farklı araştırma yöntemlerinin (ör. nitel araştırmalar) kullanılmasının bu alandaki bilgiyi artırabileceği düşünülmektedir. Son olarak, önceki çalışmalar temelinde evlilik doyumunun evliliği yaşam döngüsü içinde bulunduğu aşamaya ya da yaşa göre değişkenlik gösterebileceği bilinmektedir (Spanier vd. 1975). Mevcut çalışmada yaş aralığı geniş olduğundan, gelecekte katılımc1 verisinin yaşam döngüsünün aşamalarına ya da yaşa göre gruplanarak analiz edildiği çalışmaların yapılması önerilmektedir.

Sonuç olarak, kentte ve kırsalda yaşayan çiftlerde, farklı erken dönem uyum bozucu şemaların evlilik doyumunu açıkladığı görülmüştür. Yaşanılan yerin evlilik doyumunu etkileyip etkilemediğini inceleyen yeterli sayıda araştırma bulunmamaktadır. Bu açıdan, mevcut çalışmanın evlilik doyumu yazınına katkı sağladığı düşünülmektedir. Ruh sağlığı çalışanlarının evlilik doyumunun farklı yaşam alanlarında farklı psikolojik değişkenlerden etkileniyor olabileceği konusunda bilgi sahibi olmaları önemli görünmektedir. Ayrıca, evli bireylerde ya da çiftlerde erken dönem uyum bozucu şemalara yönelik gerçekleştirilecek şema terapinin bireysel ya da çifte yönelik uygulamalarında, evlilik doyumunun farklı şemalara göre değişkenlik gösteriyor olabileceği göz önünde bulundurulmalıdır. Buna göre, farklı uyum bozucu şemalar ile ilgili çalışmalar yaparak algılanan evlilik doyumunun artırılması olası görünmektedir. Tilden ve Dattilio (2005), bireylerin ilişkiye kendi şemalarını getirmekle birlikte ilişki içinde buna yönelik yeni şemalar da geliştirdiklerinden ve her ne kadar mevcut şemaların değiştirilmesi çok kolay olmasa da, tekrarlanan yeni deneyimlerin bunları değiştirme gücüne sahip olduğundan söz etmektedir. Ayrıca, çalışma bulguları, evlilik doyumunun genel yaşam doyumunu yansitıyor olabileceğini de göstermektedir. Yaşam doyumu, özellikle de aile yaşamına yönelik doyum, toplumsal doyum ile de yakından ilişkilidir (Toth Jr vd. 2002). $\mathrm{Bu}$ nedenle, kır ya da kentte yaşayanlar ile yapılacak doyum artırmaya yönelik müdahalelerde farklı erken dönem uyum bozucu şemaları ele 
almanın yalnızca evlilik ilişkisinin niteliğini değil, aynı zamanda toplumsal yaşamdan alınan doyumu da artırarak toplumsal düzeyde yarar sağlayabileceği düşünülmektedir.

\section{Kaynaklar}

Abelson, Robert P. vd. (1968). Theories of Cognitive Consistency: A Source- book. Chicago: Rand McNally and Company.

Altun, Gözde (2015). Evli Bireylerde Bağlanma Tarzları ve Erken Dönem Uyum Bozucu Şemaların Evlilik Doyumu ile İlişkisi. Yüksek Lisans Tezi. İstanbul: Üsküdar Üniversitesi.

Amato, Paul R. ve Jiping Zuo (1992). "Rural Poverty, Urban Poverty, and Psychological Well-Being". The Sociological Quarterly, C. 2, S. 33, s. 229-240.

Arslan, Durmuş A. ve Gülten Arslan (2015). "Kırsal Türkiye'de, Geçmişten Geleceğe Kadın, Evlilik ve Aile". Türkiyat Araştırmaları Dergisi, S. 37, s. 629-684.

Behary, Wendy T. vd. (2016). Demek Ki Oluyormuş. Çev: Nihan Azizlerli, İstanbul: Psikonet Yayınları.

Bird, Gloria W. ve Keith Melville (1994). Families and Intimate Relationships. New York, NY: McGraw-Hill Inc.

Chambers, Deborah (2012). A Sociology of Family Life: Change and Diversity in Intimate Relationships. Cambridge, UK: Polity Press.

Çağ, Pınar vd. (2013). "Evlilik Doyumunu Yordayan İlişkisel ve Kişisel Değişkenler”. Türk Psikolojik Danışma ve Rehberlik Dergisi, C. 39, S. 4, s. 13-23.

Diener, Ed vd. (1985). "The Satisfaction with Life Scale". Journal of Personality Assessment, C. 1, S. 49, s. 71-75. 
Dumitrescu, Daciana ve Alina S. Rusu (2012). "Relationship between Early Maladaptive Schemas, Couple Satisfaction and Individual Mate Value: An Evolutionary Psychological Approach". Journal of Evidence-Based Psychotherapies, S. 12, s. 63-76.

Edgerton, J. Gilbert (1983). "Models of Service Delivery". Der: Alan W. Childs ve Gary B. Melton. Rural Psychology. New York: Plenum Press, s. 275-304.

Ellis, Albert (1986). "Rational-Emotive Therapy Applied to Relationship Therapy". Journal of Rational Emotive Therapy, C. 1, S. 4, s. 4-21.

Esmaili, Saeed S. vd. (2016). "Predicting Marital Satisfaction on the Basis of Early Maladaptive Schema in Married Women, Tehran, Iran". International Journal of Medical Research \& Health Sciences, C. 6, S. 5, s. 262-270.

Fışıloğlu, Hürol (1992). "Lisansüstü Öğrencilerinin Evlilik Uyumu". Psikoloji Dergisi, S. 28, s. 16-23.

Fışıloğlu, Hürol ve Ayhan Demir (2000). “Applicability of the Dyadic Adjustment Scale for Measurement of Marital Quality with Turkish Couples". European Journal of Psychological Assessment, C. 3, S. 16, s. 214-218.

Giele, Janet Z. (2013). Family Policy and the American Safety Net. Thousand Oaks, CA: Sage.

Güncel Türkçe Sözlük. (2019a). "Kırsal [Tanım 2]”. Türk Dil Kurumu Sözlükleri içinde. http://sozluk.gov.tr (Erişim tarihi: 02.07.2019).

(2019b). "Şehir". Türk Dil Kurumu Sözlükleri içinde. http://sozluk.gov.tr (Erişim tarihi: 02.07.2019). 
Halford, W. Kim vd. (1997). "Concept of a Healthy Marriage". Clinical Handbook of Marriage and Couples Interventions, Ed: W. Kim Halford ve Howard J. Markman, New York: John Wiley \& Sons, s. 3-12.

Hatamii, Mohammad ve Mahnaz Fadayi (2015). "Effectiveness of Schema Therapy in Intimacy, Marital Conflict and Early Maladaptive Schemas of Women Suing for Divorce". International Journal of Advanced Biological and Biomedical Research, C. 3, S. 3, s. 285-290.

İmamoğlu, Olcay (1994). "Değişim Sürecinde Aile: Evlilik İlişkileri, Bireysel Gelişim ve Demokratik Değerler". Aile Kurultayı 1. Kitapçı̆̆ı. Ankara: T.C. Başbakanlık Aile Araştırma Kurulu Başkanlığı, s. 33-51.

Kağıtçıbaşı, Çiğdem (2013). Benlik, Aile ve Insan Gelişimi: Kültürel Psikoloji. İstanbul: Koç Üniversitesi Yayınları.

Kağıtçıbaşı, Çiğdem ve Zeynep Cemalcılar (2014). Dünden Bugüne Insan ve İnsanlar: Sosyal Psikolojiye Giriş. İstanbul: Evrim Yayınevi.

Kargın Güner, Zeynep (2014). Erken Dönem Uyumsuz Şemalar, İlişkilerdeki Bilişsel Süreçler, Yüklemeler, Evlilikte Sorunlarla Başa Çıma Yollarının Evlilik Uyumu ile İlişkisi. Yüksek Lisans Tezi. İstanbul: Maltepe Üniversitesi.

Kaya, Neslihan (2017). Kırsal ve Kentsel Alanda Yaşayan Evli Kadınların Evlilik Uyumu, Evlilik Doyumu ve İliskilerde Mutluluk Düzeylerinin Karşılaştırılması ve İncelenmesi. Yüksek Lisans Tezi. İstanbul: İstanbul Ticaret Üniversitesi.

Kinnunen, Ulla ve Taru Feldt (2004). "Economic Stress and Marital Adjustment among Couples: Analyses at the Dyadic Level". European Journal of Social Psychology, C. 5, S. 34, s. 519-532.

Lamke, Leanne K. (1989). "Marital Adjustment among Rural Couples: The Role of Expressiveness". Sex Roles, C. 9-10, S. 21, s. 579-590. 
Litzinger, Samantha ve Kristina Coop Gordon (2005). "Exploring Relationships among Communication, Sexual Satisfaction, and Marital Satisfaction". Journal of Sex \& Marital Therapy, C. 31, S. 5, S. 409424.

McDaniel, Susan A. vd. (2019). Close Relationships: An Introduction to the Sociology of Families (6. bask1). Ontario: Pearson Canada Inc.

Miller, Brent C. (1976). "A Multivariate Developmental Model of Marital Satisfaction". Journal of Marriage and the Family, S. 38, s. 643-657.

Morsünbül, Ümit ve Figen Çok (2011). "Bağlanma ve İlişkili Değişkenler”. Psikiyatride Güncel Yaklaşımlar, C. 3, S. 3, s. 553-570.

Nam, In S. ve Sukhee Ahn (2011). "Comparison of Stress, Social Support, and Marital Satisfaction between Married Immigrant Women in Urban and Rural Areas". Korean Journal of Women Health Nursing, C. 2, S. 17, s. 99-108.

Peen, Jaap vd. (2010). "The Current Status of Urban- Rural Differences in Psychiatric Disorders". Acta Psychiatrica Scandinavica, C. 2, S. 121, s. 84-93.

Rafaeli, Eskhol vd. (2013). Şema Terapi: Ayırıcı Özellikler. Çev: Miray Şaşıŏlu, İstanbul: Psikonet Yayınları.

Roach, Arthur J. vd. (1981). "The Marital Satisfaction Scale: Development of a Measure for Intervention Research". Journal of Marriage and the Family, C. 3, S. 43, s. 537-546.

Scanzoni, John ve Cynthia Arnett (1987). "Policy Implications Derived from a Study of Rural and Urban Marriages". Family Relations, C. 4, S. 36, s. 430-436.

Uludağ Üniversitesi Fen-Edebiyat Fakültesi Sosyal Bilimler Dergisi Uludağ University Faculty of Arts and Sciences Journal of Social Sciences Cilt: 21 Sayı: 38 / Volume: 21 Issue: 38 
Simmel, Georg (2009). Sociology: Inquiries into the Construction of Social Forms (Volume 1). Çev: Anthony J. Blasi, Anton K. Jacobs ve Mathew Kanjirathinkal. Boston: Brill.

Snyder, Douglas K. (1979). "Multidimensional Assessment of Marital Satisfaction". Journal of Marriage and the Family, C. 4, S. 41, s. 813823.

Sørensen, Jens F. L. (2014). "Rural-Urban Differences in Life Satisfaction: Evidence from the European Union". Regional Studies, S. 48, s. 1451-1466.

Soygüt, Gonca vd. (2009). "Assessment of Early Maladaptive Schemas: A Psychometric Study of the Turkish Young Schema QuestionnaireShort Form-3". Türk Psikiyatri Dergisi, S. 20, s. 75-84.

Soysal, Esra (2017). Evli Bireylerin Erken Dönem Uyumsuz Şemalarl, Illişkilerde Bilişsel Çarpıtmaları ve Yüklemelerinin Evlilik Uyumunu Yordaması. Doktora Tezi. Konya: Necmettin Erbakan Üniversitesi.

Spanier, Graham B. (1976). "Measuring Dyadic Adjustment: A New Scale for Assessing the Quality of Marriage and Similar Dyads". Journal of Marriage and the Family, S. 38, s. 15-28.

Spanier, Graham B. vd. (1975). "Marital Adjustment over the Family Life Cycle: The Issue of Curvilinearity". Journal of Marriage and the Family, C. 37, S. 2, s. 263-275.

T. C. Aile ve Sosyal Politikalar Bakanlığı (2014). Türkiye Boşanma Nedenleri Araştırması (TBNA 2014). Ankara: T.C. Aile ve Sosyal Politikalar Bakanlığı, Aile ve Toplum Hizmetleri Genel Müdürlüğü.

Tezer, Esin (1994). "Evlilik ve İş Doyumu İlişkisi: İkili Çatışmalar ve Bazı Demografik Değişkenlerin Rolü". Türk Psikolojik Danışma ve Rehberlik Dergisi, C. 2, S. 1, s. 1-12. 
Tilden, Terje ve ve Frank M. Dattilio (2005). "Vulnerability Schemas of Individuals in Couples Relationships: A Cognitive Perspective". Contemporary Family Therapy, S. 27, s. 139-162.

Toth Jr, John F. vd. (2002). "Separate Family and Community Realities? An Urban-Rural Comparison of the Association between Family Life Satisfaction and Community Satisfaction". Community, Work \& Family, C. 2, S. 5, s. 181-202.

Tutarel Kışlak, Şennur ve Fazlı Çabukça (2002). "Empati ve Demografik Değişkenlerin Evlilik Uyumu ile İlişkisi". Aile ve Toplum: Eğitim-Kültür ve Araştırma Dergisi, S. 5, s. 35-41.

Türkiye İstatistik Kurumu. "Yıllara göre İllerin Toplam Nüfusu". Veri Dosyası. https://biruni.tuik.gov.tr/ilgosterge/?locale=tr (Erişim Tarihi: 20.12.2019).

White, Lynn K. vd. (1986). "Children and Marital Happiness: Why the Negative Correlation?" Journal of Family Issues, C. 2, S. 7, s. 131147.

Yalçın, Hatice (2014). "Evlilik Uyumu ile Sosyodemografik Özellikler arasındaki İlişki”. Eğitim ve Öğretim Araştırmaları Dergisi, C. 3, S. 1, s. $250-261$.

Yıldırım, Ergün (2011). "Toplumsal Değişme Sürecinde Aile”. Aile Sosyolojisi, Ed: Kadir Canatan ve Ergün Yıldırım, İstanbul: Açılım Kitap, s. 121-138.

Yıldırım, Neşide (2004). “Türkiye'de Boşanma ve Sebepleri”. Bilig/Türk Dünyası Sosyal Bilimler Dergisi, S. 28, s. 59-81.

Y1ldı, Özge Zelal (2018). Evlilik Doyumunun Öncülleri ve Sonuçları: Depresyon, Kaygl, Erken Dönem Uyumsuz Şemalar. Yüksek Lisans Tezi. İstanbul: Iş̧1 Üniversitesi. 
Y1lmaz, Murat (2015). "Türkiye'de Kırsal Nüfusun Değişimi ve İllere Göre Dağılımı (1980-2012)”. Doğu Coğrafya Dergisi, S. 33, s. 161188.

Young, Jeffrey E. (1990). Cognitive Therapy for Personality Disorders: A Schema-Focused Approach. Sarasota, FL: Professional Resource Press.

Young, Jeffrey E. (1999). Cognitive Therapy for Personality Disorders: A Schema-Focused Approach (Gözden geçirilmiş baskı). Sarasota, FL: Professional Resource Press.

Young, Jeffrey E. ve Janet S. Klosko (1994). Reinventing Your Life: How to Break Free from Negative Life Patterns. New York, NY: Plume.

Young, Jeffrey E. vd. (2003). Schema Therapy. New York, NY: Guilford.

Yousefi, Naser vd. (2010). "Comparing of Early Maladaptive Schemas among Divorced and Non-Divorced Couples as Predictors of Divorce". Iranian Journal of Psychiatry and Clinical Psychology, C. 1, S. 16, s. 21-33.

Yüksel, Özge ve İhsan Dağ (2015). "Kadınlarda Evlilik Uyumu ve Psikolojik Belirtiler Arasındaki İlişki: Stresle Baş Etme Biçimleri ve Toplumsal Cinsiyet Rolü Tutumlarının Aracı Rolleri”. Türk Psikiyatri Dergisi, C. 3, S. 26, s. 181-188. 


\section{EXTENDED ABSTRACT}

Marriage, being the most intimate relationship for many individuals in the community, is influenced by a variety of individual, relationship and / or community characteristics. It has been assumed that similar to the partners' individual characteristics or marital characteristics, the place of couples' residence would also influence satisfaction derived from the marital relationship. The aim of the current study was to investigate the impact of the place of residence on marital satisfaction and early maladaptive schemas (EMS) of married individuals.

The sample consisted of 268 married individuals between 18-65 ages. 120 participants were living in rural and 168 were living in urban areas at the time of data collection. The participants were from three different cities in Turkey (Ankara, Kirlkkale, Manisa). The participants were given a demographic information form, along with Young Schema Questionnaire-Short Form 3 (Young et al. 1990; 2003; Soygüt et al. 2009), and Dyadic Adjustment Scale (Spanier 1976; Flşıloğlu et al. 2000).

Findings showed that the level of marital satisfaction was higher in married individuals living in rural areas compared to individuals in urban areas. Examining group differences in the domains of marital satisfaction, it was shown that the rural and urban samples differed in all domains except cohesion. Dyadic cohesion involves the degree to which partners engage in shared activities, etc. From a developmental perspective, attachment is mostly to romantic partners in adult years (Morsünbül et al. 2011). Individuals derive their needs for intimacy and closeness from their spouses in their marriages. Therefore, this result may be reflecting that attachment is a basic need and may not change depending on the place of residence.

When EMS scores of individuals living in rural or urban areas were examined, it was found that participants from rural areas had higher scores at six EMSs compared to participants from urban areas. These were emotional inhibition, approval seeking / recognition seeking, self-sacrifice, punitiveness, vulnerability to harm and illness, and unrelenting standards. These schemas are involved in all schema domains except in impaired limits. This was thought to reflect an increased cognitive vulnerability for married individuals living in rural areas, as EMSs have been known to result in vulnerability from a cognitive perspective (Tilden et al. 2005).

In the main analysis, demographic variables were entered in the first step. It was found that none of the demographic variables (i.e., gender, age, level of education, working status, and level of income) predicted marital satisfaction in the 
rural or the urban sample in the study. Studies in the literature (e.g., Tutarel Kişlak et al. 2002; Tezer 1994) have previously showed mixed findings regarding the relationship between marital satisfaction and demographic variables. Hence, it is important for future studies to examine this relationship in diverse samples by taking community variables such as place of residence into consideration. In the second step, only the number of children predicted marital satisfaction in the rural sample; showing that as the number of children increased, the perceived level of marital satisfaction decreased.

In addition, in the main analyses, different EMSs predicted marital satisfaction for individuals in rural or urban areas. Only emotional deprivation was a common EMS for both samples. In the urban sample, marital satisfaction was also predicted by social isolation / mistrust in the expected direction. In the rural sample, however, three additional EMS predicted the level of marital satisfaction: failure, punitiveness, and vulnerability to harm and illness. This schemas was positively related to satisfaction; in other words, individuals with these schemas had higher marital satisfaction. This counterintuitive finding might be related to the tendency of individuals with these schemas to limit their lives to avoid risk and harm (Young et al. 2003) and also to engage in schema compensation strategies to avoid the emotional pain and vulnerability associated with schemas. Thus, they might have perceive their marital life unrealistically. Nevertheless, future studies should aim to further elaborate the relationship between EMSs and marital satisfaction in rural settings.

The current study is the first in the literature to investigate marital satisfaction and EMSs together in both rural and urban samples. It has been found that marital satisfaction might be affected by distinct factors in rural and urban areas. It seems important for mental health professionals working with married individuals and / or couples to take this into consideration. It is possible that marital satisfaction is closely related with general life satisfaction, and thus with community satisfaction (Toth $\mathrm{Jr}$ et al. 2002). Therefore, any interventions aimed to increase marital satisfaction in rural and urban areas would also help to increase both life and community satisfaction. 